\title{
Molecular Epidemiology and Emergence of Rift Valley Fever
}

\author{
AA Sall ${ }^{+}$, PMA Zanotto*, P Vialat**, OK Sène, M Bouloy**
}

\author{
Institut Pasteur de Dakar, BP 220, Dakar, Senegal *Departamento de Microbiologia, Instituto de Ciências \\ Biomédicas, Universidade de São Paulo, Cidade Universitária, 05508-900 São Paulo, SP, Brasil \\ **Institut Pasteur, 25, Rue du docteur Roux, 75724 Paris cedex 15, France
}

Rift Valley fever (RVF) is a mosquito-borne viral disease which manifested itself during recent epidemics and revealed its significant potential of emergence. Studies on molecular epidemiology undertaken to better understand the factors leading to RVF emergence, have confirmed the mode of circulation of the virus and highlithted probable risks and obstacles for prevention and control. As for several other viral agents, molecular epidemiology is becoming a useful tool in the study of the emergence of $R V F$ as a serious infectious disease.

Key words: arboviruses - Rift Valley fever - molecular epidemiology - emergence - phylogeny

Rift Valley fever (RVF) is an arboviral disease transmitted by mosquitoes in Africa. RVF affects primarily ruminants causing high mortality in offspring and abortions in pregnants females and occasionally humans, whose infection leads to a clinical picture which ranges from a mild febrile case to hemorragic fever with complications such as hepatitis, encephalitis and retinitis (Laughlin et al. 1979). In 1977, a severe outbreak of RVF occurred in human and livestock populations of Egypt (Meegan 1981). Although RVF was known for more than 40 years at that time, the extensive morbidity and mortality observed in humans appeared as a novelty in the history of this disease, therefore, emphasizing RVF as a serious emerging threat for humans and animals health. Futher large scale epidemics in Mauritania (Digoutte \& Peters 1989), Madagascar (Morvan et al. 1991, 1992a, b), Egypt (Arthur et al. 1993) and very recently in eastern Africa (Anonymous 1998) confirmed the major impact of RVF on public health through its continuing emergence. Thus, RVF constitutes an excellent model to overview factors involved in arboviruses emergence because most of the concepts relative to emerging diseases may be illustrated along its natural history.

Control of RVF implies the better identification of factors involved in its emergence and its maintenance in nature. It is also necessary to un-

\footnotetext{
${ }^{+}$Corresponding author. Fax: +221.839.92.10. E-mail: sall@pasteur.sn

Received 15 June 1998

Accepted 30 July 1998
}

derstand the rules and modalities of circulation and evolution of RVF virus (RVFV) in Africa. These latter objectives have been addressed by studying the variability among RVFV isolates by serological (Besselar et al. 1991) and molecular methods (Battles \& Dalrymple 1988, Sall et al. 1997a, b). This paper aims the discussion of some of the aspects and contributions of molecular epidemiology towards the elucidation of RVF emergence.

\section{BACKGROUND}

\section{Discovery of RVFV and recent major epidemic/ epizootics}

RVFV was first isolated in 1930 near lake Naivasha in Kenya by Daubney et al. (1931). Since then, the virus has been shown to be widespread in subsaharian Africa and in Egypt (Meegan \& Bailey 1989). Major epidemic/epizootics occurred in Egypt in 1977 (200,000 humans infections and 600 deaths) and in 1993, Mauritania in 1987 (200 human deaths), Madagascar in 1991 and in eastern Africa $(89,000$ infections and more than 500 deaths reported so far) with the last recent outbreak in 1997-1998 in Kenya, Tanzania, Somalia.

\section{The etiological agent of RVF}

RVFV is a member of Bunyaviridae family, Phlebovirus genus (Murphy et al. 1995). Its genome consists in three negative single stranded RNA segments referred as L, M and S respectively for large, medium and small. The $\mathrm{L}$ segment codes for the $\mathrm{L}$ protein which is the viral polymerase. The $\mathrm{M}$ segment codes for glycoproteins $\mathrm{G1}$ and $\mathrm{G} 2$ and two others proteins of 78 and $14 \mathrm{~K}$. The S segment codes for the nucleoprotein $\mathrm{N}$ and the non structural NSs protein using an ambisense strategy (Bouloy 1991, Elliott et al. 1991, Giorgi 1996, Schmaljohn 1996). 


\section{Epidemiology of RVF}

The epidemiology of RVF consists in both epizootic and interepizootic cycles (Meegan \& Bailey 1989). Epizootics of RVF in Africa occured often when unusually heavy rainfall were observed. During an epizootic, virus circulates among infected arthropod vectors and mammalian hosts, particularly cattle and sheep, which represent the most significant livestock amplifiers of RVFV. The inter-epizootic survival of RVFV is believed to depend on transovarial transmission of virus in floodwater Aedes mosquitoes (Linthicum et al. 1985). Virus can persist in mosquitoes eggs until the next period of heavy rainfall when they hatch and yield RVFV infected mosquitoes. Depending on factors such as availability of sufficient numbers of competent mosquito vectors, presence of susceptible vertebrates, appropriate environmental conditions, infected mosquitoes have the potential to infect a relatively small number of vertebrate hosts or to initiate a widespread RVF epizootic.

\section{Control and prevention of RVF}

Vaccines have been the principal mean used to control RVF. Two types of vaccines have been described for use against RVF: inactivated and liveattenuated.

Formalin-inactivated RVF vaccines have been used to immunize animals, laboratory workers, veterinarians and other people at high risk of exposure to RVFV. The cost of the vaccine, the requirement for multiple inoculations and the time interval required to mount a protective immune response, all limit its use for veterinary purposes.

Two live attenuated vaccines, the Smithburn vaccine, also referred as Smithburn neurotropic strain or SNS (Smithburn et al. 1949), and MP12 (Caplen et al. 1985) have been developped. The Smithburn strain is the only widely available veterinary vaccine but has serious limitations in practical use, because it has been proven to be teratogenic, cause abortions and encephalitis in young lambs.

Possessing attenuation markers in all three segments, MP12 has a very low probability of reversion (Saluzzo \& Smith 1990, Vialat et al. 1997) and has been inoculated into more than 100 people and shown to be safe and immunogenic (Peters 1997). MP12 was also promising in laboratory trials in domestic animals (Morrill et al. 1987, Morril \& Mc Clain 1996), but vaccination of pregnant ewes revealed that the virus caused teratogenic effect if inoculated during the first trimester of pregnancy (Erasmus and Bishop, pers. commun.). Another attenuated virus, clone 13 , a naturally attenu- ated strain, is very promising regarding the preliminary results obtained in terms of immunogenicity and safety (Muller et al. 1995).

\section{MOLECULAR EPIDEMIOLOGY OF RVFV}

Investigation on the variation among RVFV isolates using serological tests based on the antigenicity of structural proteins (Saluzzo et al. 1989a,b, Besselar et al. 1991) or genetic methods such as T1-oligonucleotide fingerprints (Peters \& Linticum 1994) and, more recently sequencing, (Battles \& Dalrymple 1988) indicated only minor variations among RVFV natural isolates. To further analyze the genetic diversity of RVFV (Sall et al. 1997b), we selected a panel of 18 strains (Table I) isolated over some 50 years from various hosts and geographical origins and we sequenced directly their NSs coding region on the S segment after a step of reverse transcription-polymerase chain reaction amplification (RT/PCR). A 50\% majority rule consensus tree derived from the sequences analyzed are presented in Fig. 1. The NSs coding region sequences clustered in three major lineages supported by high bootstrapping values and by using different phylogenetic inference procedures (e.g., maximum likelihood, parsimony and distance methods) and correlated with the geographic origin of the isolates and are referred as West Africa, East-Central Africa and Egypt. While the West Africa group was homogenous with strains from Mauritania, Senegal, Guinea and Burkina Faso, the East-Central Africa and Egypt ones appeared to be heterogenous.

As expected, the Egyptian group contains strains isolated in 1977 and 1993 epidemics, which appear in the phylogeny as sister groups suggesting that either the virus remained endemic between the two outbreaks or have been reintroduced in 1993 from the same source (probably Sudan) as in 1977. To explain the reemergence of RVF in Egypt after years of silence despite intensive surveillance, Peters (1997) proposed that the virus was reintroduced through an incompletely inactivated RVF veterinary vaccine. Furthermore, Ar MAD 79, which is the first isolation of RVFV in Madagascar, clustered in Egypt group and then confirmed data obtained by Morvan et al. (1991) who analyzed the antigenic properties of the $\mathrm{N}$ protein.

Secondly, the East-Central African group clustered isolates from Uganda, Central African Republic, Mauritania and Senegal. The presence of An MAD 91 in that group suggested that this latter strain was probably introduced in Madagascar from the eastern coast of Africa. This latter assumption also implies that there was at least two introductions of the virus in Madagascar but also several lineages coexist in East Africa. Moreover, in 
TABLE I

Characteristics of the Rift Valley fever virus isolates analyzed by sequencing

\begin{tabular}{lllll}
\hline Code & Strain & Year of isolation & Origin & Source \\
\hline SNS & Smithburn & 1944 & Uganda & Entebbe strain \\
Ar UG 55 & Lunyo & 1955 & Uganda & Mosquito \\
Ar RCA 69 & Ar B 1976 & 1969 & CAR & Mosquito \\
H EGY 77 & ZH 548 & 1977 & Egypt & Human \\
MP 12 & MP12 & 1985 & Egypt & ZH548 strain \\
Ar MAD 79 & Ar Mg 811 & 1979 & Madagascar & Mosquito \\
Ar SEN 84 & Ar D 38661 & 1984 & Senegal & Mosquito \\
An GUI 84 & An K 6087 & 1984 & Guinea & Bat \\
Ar BUF 84 & Ar D 38457 & 1984 & Burkina Faso & Mosquito \\
H1 MAU 87 & H D 47502 & 1987 & Mauritania & Human \\
H2 MAU 87 & H D 47311 & 1987 & Mauritania & Human \\
H3 MAU 87 & H D 47408 & 1987 & Mauritania & Human \\
H4 MAU 87 & H D 48255 & 1987 & Mauritania & Human \\
An MAD 91 & An Mg 990 & 1991 & Madagascar & Bovine \\
Ar SEN 93 & Ar D 104769 & 1993 & Senegal & Mosquito \\
An SEN 93 & An D 106417 & 1993 & Senegal & Zebu \\
B EGY 93 & B EGY 93 & 1993 & Egypt & Buffalo \\
H EGY 93 & H EGY 93 & 1993 & Egypt & Human \\
\hline
\end{tabular}

$a$ : laboratory-attenuated strain derived from a wild strain; SNS: Smithburn neurotropic strain; H: human; Ar: arthropode; An: animal; B: buffalo.

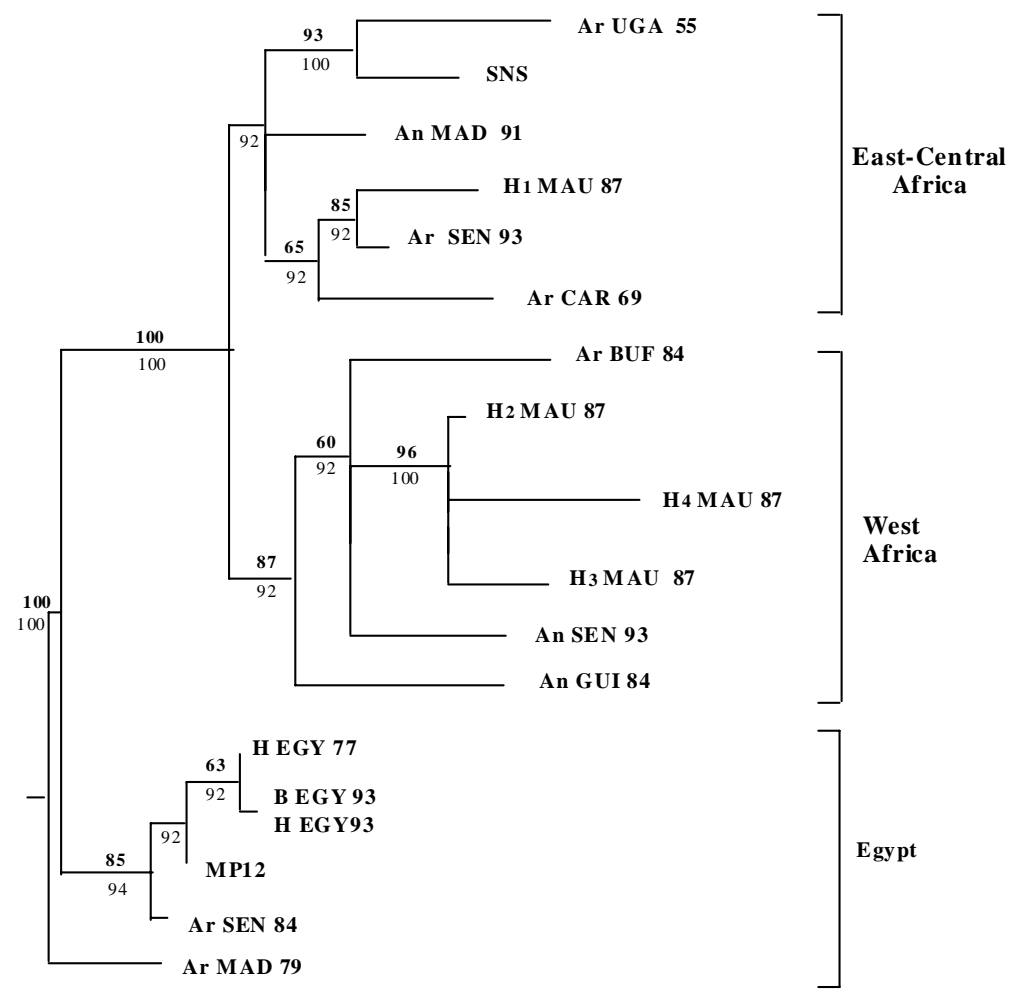

Fig. 1: phylogenetic tree for the NSs gene of several Rift Valley fever virus isolates. Values above branches indicate the level (\%) of bootstrap support using maximum parsimony after 500 iterations. Values below branches indicate the number of times a given node was observed on a majority rule consensus of 50 trees with equivalent likelihood (LnL). Branch lengths are shown proportional to the number of substitutions per 100 residues. The rooting shown here was determined by the inclusion of the SSF NSs sequence. 
Uganda, despite 11 years separating the isolations of Ar UGA 55 and Entebbe strain, the parental strain of Smithburn vaccinal strain, RVFV did not show much genetic diversity, suggesting a maintenance mechanism through an endemic/enzootic cycle, possibly involving comparatively little viral activity, since increased genetic diversity for a given mutation rate entails an increase on the effective viral population size. Surprisingly, H1 MAU 87 and Ar SEN 93 belonged to the EastCentral Africa group.

The West Africa group appeared to be homogenous and suggested circulation of similar variants in Senegal, Mauritania, Guinea and Burkina Faso. It is noteworthy that $\mathrm{H} 2,3$, and 4 MAU 87 clustered near each other and were isolated from fatal cases whereas H1 MAU 87 which was isolated from a febrile case clustered together with Ar SEN 93 unexpectedly in the East-Central Africa lineage. Moreover, one may deduced, from the strains distribution on Fig. 1, that there are two areas of circulation of RVFV in Senegal: (i) the Northern Sahelian zone where Ar SEN 93 and H1 MAU 87 were isolated and, (ii) the Sudano-Guinean zone where An SEN 93 was isolated.

Groupings of Ar SEN 84 with Egyptian strains on one hand and H1MAU 87 and Ar SEN 93 with eastern and central African strains on the other hand, were quite unexpected and led us to hypothesize genetic exchange through reassortment to explain these puzzling clusterings. In order to check this hypothesis further sequencing and phylogenetic analysis were undertaken both on $\mathrm{L}$ and $\mathrm{M}$ segments. Although, this hypothesis is still under investigation, one may obviously speculate by anticipation that such a mechanism in natura would have important implications on epidemiology and emergence of RVF in Africa (see below).

\section{EMERGENCE OF RVFV}

Various factors contributing to the emergence of infectious diseases were classified by Lederberg et al. (1992) and analyzed from the point of view of RVF by Wilson (1994) and summarized in Table II. Emergence of RVF was also discussed by Peters (1997) with special reference to Madagascar, distant spread of the virus to Egypt and historical speculations. These two papers emphasized the multifactorial aspect of RVF emergence and the central role of water and ecological change as factors triggering epidemics. Water is usually involved either through dams or irrigation for the sake of agriculture development, as illustrated by Egypt in 1977 and Mauritania in 1987 or, under excessive rainfall and floodings as observed during the 1997-98 outbreak in eastern Africa. Concerning the impact of ecological changes as deforestation
TABLE II

Summary of Rift Valley fever (RVF) emergence factors described and analyzed by Wilson (1994)

\begin{tabular}{|c|c|}
\hline Factors of emergence & Examples relative to RVF \\
\hline $\begin{array}{l}\text { Economic development/ } \\
\text { Land use }\end{array}$ & $\begin{array}{l}\text { Dams and irrigation, } \\
\text { pasturage improvement }\end{array}$ \\
\hline $\begin{array}{l}\text { Human demography and } \\
\text { behavior }\end{array}$ & $\begin{array}{l}\text { Living with domestic } \\
\text { ungulates, slaughter of sick } \\
\text { animal, Vaccination of } \\
\text { healthy animals }\end{array}$ \\
\hline $\begin{array}{l}\text { International travel and } \\
\text { commerce }\end{array}$ & $\begin{array}{l}\text { Domestic ungulates export, } \\
\text { human travel and } \\
\text { migration }\end{array}$ \\
\hline $\begin{array}{l}\text { Biological adaptation } \\
\text { and change }\end{array}$ & $\begin{array}{l}\text { Increased viral virulence, } \\
\text { improved vector } \\
\text { competence, greater } \\
\text { animal susceptibility }\end{array}$ \\
\hline Climate events & Excessive rainfall \\
\hline
\end{tabular}

and agricultural pratices change, the outbreak in Madagascar in 1991 has been shown to be a very instructive example (Peters \& Linthicum 1994, Peters 1997).

Although these two key factors were clearly identified and characterized, data derived from molecular epidemiology are needed for a comprehensive view of RVF and its emergence process. Our work, although still preliminary allowed to illustrate the contribution of molecular epidemiology for, (i) the understanding of two modes of circulation of viral strains and (ii) delineation of genetic aspects of the virus, which may turn out to become potential obstacles for the prevention and control of the disease.

\section{Modes of circulation of RVFV}

Regarding the molecular epidemiology data about RVFV, two modes of circulation may be illustrated (Fig. 2): (i) distant spread from one region to another and (ii) local circulation in an enzootic/endemic area.

Distant spread was illustrated by introduction of RVFV in Egypt (1977) and Madagascar (1979 and 1991) probably from eastern or central Africa (see molecular epidemiology). It is interesting to emphasize that in both cases, possibly an antigenically and phylogenetically "new" virus was introduced in an area exempt of RVFV, raising the issue about the role of herd immunity for both, humans and animals populations, as a factor of emergence of the virus.

Concerning local circulation in an enzootic/ endemic area, Senegal is an instructive example 


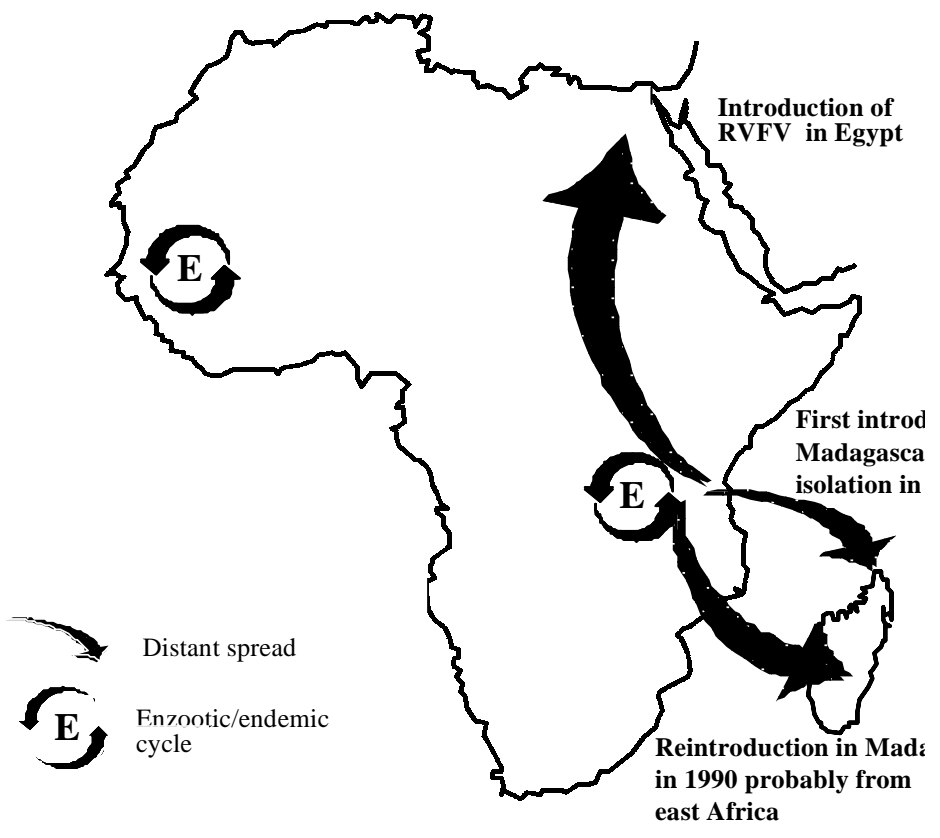

Fig. 2: possible modes of circulation of Rift Valley fever.

because it showed reemergence of the virus from a pool of existing enzootic/endemic strains under a similar process although the ecological context of transmission is different between the north and the south of that country. As far as RVF is concerned, Senegal can be divided in two areas (Sall et al. 1997b) from which the virus have emerged as demonstrated by isolations in 1993 (Zeller et al. 1997): (i) the Sahelian zone, where southern Mauritanian and northern Senegalese strains are circulating and, (ii) the Sudano-Guinean zone where southern Senegalese strains are in contact with those from bordering countries.

\section{Prevention and control}

In the field of prevention and control of RVFV, molecular epidemiology studies highlighted a potential major obstacle to the use of live attenuated vaccines. Indeed, the possibility of the existence of reassortment in nature raised by the unexpected groupings (Ar SEN 84, H1 MAU 87 and Ar SEN 93) would emphasize the risk of generating uncontrolled chimeric viruses.

\section{CONCLUSION}

Although molecular epidemiology has been shown to be informative for a better understanding on different facets of RVFV emergence, many questions such as those relative to the sylvatic cycle of the virus for instance remain unanswered. Mean- while, surveillance of RVF and awareness should be improved and reinforced since it is so far the only conceivable way to prevent RVFV emergence with its toll of deaths, sickness and economic loss.

\section{ACKNOWLEDGEMENTS}

To C Mathiot and J Thonnon for critically reading the manuscript.

\section{REFERENCES}

Anonymous 1998. An outbreak of Rift Valley fever, Eastern Africa, 1997-1998. WER 73: 105-112.

Arthur R, El-Sharkawy MS, Cope SE, Botros BA, Oun S, Morrill JC, Shope RE, Hibbs RG, Darwish MA, Imam IZE 1993. Recurrence of Rift Valley fever in Egypt. Lancet 342: 1149-50.

Battles JK, Dalrymple JM 1988. Genetic variation among geographic isolates of rift valley fever virus. Am J Trop Med Hyg 39: 617-631.

Besselar TG, Blackburn NK, Meenehan GM 1991. Antigenic analysis of Rift Valley fever isolates: monoclonal antibodies distinguish between wild-type and neurotropic virus strains. Res Virol 142: 469-474.

Bouloy M 1991. Bunyaviridae: Genome organization and replication strategies. Adv Vir Res 40: 235-266.

Caplen H, Peters CJ, Bishop DHL 1985. Mutagen-directed attenuation of Rift Valley fever virus as a method for vaccine development. J Gen Virol 66: 2271-2277.

Daubney R, Hudson JR, Garnham PC 1931. Enzootic hepatitis or Rift Valley fever. An undescribed virus disease of sheep, cattle and man from East Africa. $J$ Pathol Bacteriol 34: 545-79. 
Digoutte JP, Peters CJ 1989. General aspects of the 1987 Rift Valley fever epidemic in Mauritania. Res Virol 140: 27-30.

Elliott RM, Schmaljohn CS, Collett MS 1991. Bunyaviridae genome structure and gene expression. Curr Top Micro Immunol, Springer- Verlag, Berlin: 91-142.

Giorgi C 1996. Molecular biology of phleboviruses, p. 105-128. In RM Eliott, The Bunyaviridae, Plenum Press, New York.

Laughlin LW, Meegan JM, Strausbaugh LW, Morens DM, Watten RH 1979. Epidemic Rift Valley fever in Egypt: observations of the spectrum of human illness. Trans $R$ Soc Trop Med Hyg 73: 630-633.

Lederberg J, Shope RE, Oaks SC 1992. Emerging Infections, Microbial Threats to Health in the United States, National Academy Press, Washington, DC.

Linthicum KJ, Davies FG, Kairo A 1985. Rift Valley fever virus (family Bunyaviridae, genus Phlebovirus). Isolations from Diptera collected during an inter-epizootic period in Kenya. J Hyg Camb 95: 197-209.

Meegan JM 1981. Rift Valley fever in Egypt. An overview of epizootics in 1977 and 1978. Contrib Epidemiol Biostat 3: 100-113.

Meegan JM, Bailey CJ 1989. Rift Valley fever, p. 5176. In TP Monath, The Arboviruses: Epidemiology and Ecology IV, CRC Press Inc., Boca Raton, Fl.

Morvan J, Saluzzo JF, Fontenille D, Rollin PE, Coulanges P 1991. Rift Valley fever in the east coast of Madagascar. Res Virol 142: 475-482.

Morvan J, Rollin PE, Laventure S, Rakotoarivony I, Roux J 1992a. Rift Valley fever epizootic in the central highlands of Madagascar. Res Virol 143: 407415.

Morvan J, Rollin PE, Roux J 1992b. La fièvre de la Vallée du Rift à Madagascar en 1991. Enquête séroepidémiologique chez les bovins. Rev Ele Med Pay Trop 45: 121-127.

Morrill JC, Mc Clain DJ 1996. Epidemiology and pathogenesis of Rift Valley fever and other phleboviruses. p. 281-294 In RM Elliott, The bunyaviridae, Plenum Press, New York.

Morrill JC, Jennings GB, Caplen H, Turell MJ, Johnson AJ, Peters CJ 1987. Pathogenicity and immunogenicity of a mutagen-attenuated Rift Valley fever virus immunogen in pregnant ewes. Am J Vet Res 48: 1042-1047.

Muller R, Saluzzo JF, Lopez N, Dreier T, Turell M, Smith J, Bouloy M 1995. Characterization of clone 13, a naturally attenuated avirulent isolate of Rift Valley fever virus, which is altered in the small segment. Am J Trop Med Hyg 53: 405-411.

Murphy FA, Fauquet CM, Bishop DHL, Ghabrial SA, Jarvis AW, Martelli GP, Mayo MA, Summers MD
1995. Family Bunyaviridae, p. 300-315. In Virus Taxonomy. Classification and Nomenclature of Viruses. Sixth report of the international committee on taxonomy of viruses. Springer-Verlag, Wien, New York.

Peters CJ 1997. Emergence of Rift Valley fever, p. 253264. In JF Saluzzo, B Dodet (eds), Factors in the Emergence of Arbovirus Diseases, Elsevier, Paris.

Peters CJ, Linthicum KJ 1994. Rift Valley fever, p. 125138. In Beran GW, Steele JH (eds), Hanbbook of Zoonoses, Section B: Viral, 2nd ed., CRC Press, Boca Raton, Fl.

Sall AA, Zeller H, Zanotto PM de A, Billecocq A, Vialat P, Préhaud C, Yadani F, Bouloy M 1997a. Rift Valley Fever virus: the NSs protein as a target to evaluate genetic variability and its roles in pathogenesis, p. 265-271. In JF Saluzzo, B Dodet (eds), Factors of Emergence of Arboviruses, Elsevier, Paris.

Sall AA, Zeller H, Thiongane Y, Digoutte JP, Bouloy M 1997b. Genetic variability of the NSs protein among Rift Valley Fever Virus isolates. J Gen Virol 78: 2853-2858.

Saluzzo JF, Smith JF 1990. Use of reassortants viruses to map attenuating and temperature sensitive mutations of the Rift Valley fever virus MP12 vaccine. Vaccine 8: 369-75.

Saluzzo JF, Anderson GW, Smith JF, Fontenille D, Coulanges P 1989a. Biological and antigenic relationship between Rift Valley fever virus strains isolated in Egypt and Madagascar. Trans $R$ Soc Trop Med Hyg 83: 701.

Saluzzo JF, Anderson GW, Hodgson LA, Digoutte JP, Smith JF 1989b. Antigenic and biological properties of Rift Valley fever isolated during the 1987 Mauritanian epidemic. Res Virol 140: 155-64.

Schmaljohn CS 1996. Bunyaviridae: the viruses and their replication, p. 1447-1471. In Fields BN, Knipe DM, Howley PM (eds), Fields Virology, 3rd ed., Raven Press, New York.

Smithburn KC 1949. Rift Valley fever: the neurotropic adaptation of the virus and the experimental use of this modified virus as a vaccine. Brit J Exp Path 30: $1-16$.

Vialat P, Muller R, Vu TH, Prehaud C, Bouloy M 1997. Mapping of the mutations present in the genome of Rift Valley fever virus attenuated MP12 strain and their putative role in attenuation. Virus Research 52: 43-50.

Wilson ML 1994. Ecology and the epidemiology of disease emergence. Ann New York Acad Sci 740: 169180.

Zeller HG, Fontenille D, Traoré-Laminzana M, Thiongane Y, Digoutte JP 1997. Enzootic activity of Rift Valley fever virus in Senegal. Am J Trop Med Hyg 56: 265-272. 